\title{
GEOLOGICAL MAP OF THE RODMAN MOUNTAINS QUADRANGLE SAN BERNARDINO COUNTY, CALIFORNIA \\ By
}

T. W. Dibblee, Jr.

MISCELLANEOUS GEOLOGIC INVESTIGATIONS

MAP I-430

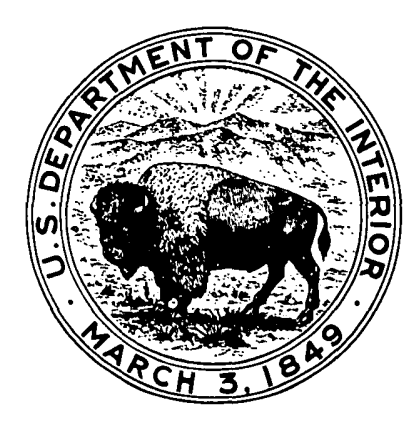




\title{
GEOLOGIC MAP OF THE RODMAN MOUNTAINS QUADRANGLE SAN BERNARDINO COUNTY, CALIFORNIA
}

\author{
By
}

\author{
T. W. Dibblee, Jr.
}

\section{DESCRIPTION OF THE MAP UNITS}

\section{PRE-MESOZOIC METAMORPHIC ROCKS Gneiss}

Dark-gray medium- to coarse-grained gneiss composed of quartz, potassic feldspar, sodic plagioclase, biotite, and hornblende in variable proportions; crudely banded, some bands light gray, richer in feldspar and quartz. Small lenses of gneiss within biotite quartz monzonite commonly migmatic. Recrystallized from Precambrian(?) metasedimentary rocks.

\section{Metasedimentary rocks}

Metamorphosed marine sedimentary rocks exposed as pendants engulfed chiefly in biotite quartz monzonite; greatest exposed thickness about 1,000 feet. Rocks unfossiliferous but lithologically similar to metasedimentary rocks of late Paleozoic age in San Bernardino Mountains (Vaughan; 1922). Composed of the following units:

Quartzite.-White, light-gray, $\tan$ to pink quartzite with much brown iron staining on fractures; massive to locally banded; extremely hard, subvitreous but brittle, closely fractured, fine-grained; composed mostly of quartz, locally contains some feldspar and sericite. Similar to, and possibly correlative with, Saragossa Quartzite of San Bernardino Mountains (Vaughan, 1922).

Metaconglomerate:-Gray-brown, massive to poorly bedded, composed of subrounded pebbles ard cobbles of felsitic(?) rocks in hard brown fine-grained matrix.

Limestone or marble. - White to gray-white, mediumto coarsely crystalline, thick-bedded, composed of calcite and some dolomite; adjacent to granitic contacts commonly contains epidote, garnet, and diopside. Similar to, and possibly correlative with, Furnace Limestone (Paleozoic) of San Bernardino Mountains (Vaughan, 1922).

Tactite.-Greenish- to reddish-brown, massive to thickbedded, finely to coarsely crystalline, hard tactite composed mainly of garnet, diopside, epidote, and wollastonite. Presumably formed by silication of marble.

Iron oxide.-Black to dark greenish-brown massive iron ore composed mostly of hematite and magnetite with some epidote, diopside, and garnet. Formed by replacement of marble along contact with biotite quartz monzonite.

\section{MESOZOIC PLUTONIC AND HYPABYSSAL IGNEOUS ROCKS Hornblende diorite gabbro}

Black, massive, medium-grained, locally fine- or coarsegrained diorite and(or) gabbro composed mostly of horn- blende and plagioclase (labradorite) in variable proportions; some biotite, epidote and magnetite; epidote veinlets common. Age, presumably Mesozoic.

\section{Older granitic rocks}

Quartz-bearing granitic rocks mostly of quartz monzonite composition but ranging from granite to granodiorite or even quartz diorite. Age, Mesozoic; intrusive into metamorphic rocks. Composed of the following units:

Biotite quartz monzonite. - Gray, locally dark-gray or nearly white, medium- to coarse-grained, commonly porphyritic, massive to gneissic granitic rock composed of quartz, potassic feldspar (orthoclase), and plagioclase (oligoclase or andesine) in about equal proportions or with plagioclase slightly predominant, 5 to 20 percent biotite, 0 to 10 percent hornblende, and a total of about 1 percent of magnetite, sphene, apatite, and zircon. Biotite forms numerous minute flakes irregularly distributed as clusters that impart dark color to rock. Porphyritic facies contains scattered to numerous phenocrysts of potassic feldspar as long as $2 \mathrm{~cm}$. Gneissic facies commonly contains scattered lenticular dark-gray fine-grained dioritic inclusions as long as $30 \mathrm{~cm}$ flattened parallel to gneissoid foliation of rock. In many places rock affected by cataclastic shearing and hydrothermal (or deuteric?) alteration, with biotite altered to limonite or even leached out leaving rock nearly white, feldspars partly altered to sericite, and hornblende partly replaced by epidote, chlorite, and iron oxides. Veinlets and streaks of epidote common in altered rock.

Leucocratic quartz monzonite. - White, massive, mediumto coarse-grained, hard granitic rock composed almost entirely of quartz and sodic plagioclase; rock much affected by cataclastic and hydrothermal (or deuteric?) action, with biotite leached out; rock possibly altered or bleached from biotite quartz monzonite in which potassic feldspar may have been altered to albite.

Mixed quartz monzonites. - Mostly biotite quartz monzonite complexly intruded by granite and quartz monzonite unit; in places contains, small masses of hornblende diorite gabbro.

Granite and quartz monzonite.-Gray-white, buff-weathering, massive, hard, medium- to fine-grained granitic rock composed of quartz, potassic feldspar (orthoclase), and sodic plagioclase in generally equal proportions but with slight predominance of potassic feldspar over plagioclase, 1 to 2 percent biotite, and a total of about 1 percent of muscovite, 
sphene, apatite, and iron oxides; biotite forms very small flakes partly altered to limonite. Intrusive into biotite quartz monzonite, intruded by porphyry complex.

\section{Aplitic quঞrtz monz@mite}

Gray-white, buff-weathering, hard, massive, fine-grained granitic rock composed of quartz, potassic feldspar, and sodic plagioclase in generally equal proportions; commonly contains scattered small phenocrysts of feldspar with poorly defined borders. Rlay be aplitic facies of porphyry complex. Age, presumably Mesozoic.

\section{Porployry complex}

Includes Ord Mountain Group of Gardner (1940). Complex slightly to moderately metamorphosed porphyritic igneous rocks with aphanitic to fine-grained groundmass. Forms masses and dikes intrusive into older granitic rocks; in some large masses possibly in part extrusive. Age; Mesozoic, probably Early Cretaceous or older. Composed of the following rock units:

Siliceous felsite and aplite. - White to light-gray, generally massive to locally faintly flow-laminated, very hard, commonly porcelaneous, aphanitic (microcrystalline) to fine-grained (aplitic). Composed mostly of quartz and sodic plagioclase. Contains few small phenocrysts of plagioclase (albite) with indistinct boundaries (partly resorbed?). In places rock contains fine-grained streaks and blotches of dark minerals (biotite and iron oxides?). . Forms pods in latite porphyry; forms felsite dike that transects dikes of latite porphyry 2 miles N. $30^{\circ} \mathrm{E}$. of south west corner of quadrangle, but in area about 4 miles farther northeast forms aplitic dikes transected by dikes of latite porphyry.

Quartz latite.-Gray-white, weathers tan, with much reddish-brown iron staining on fracture surfaces; moderately hard, massive to slightly foliated parallel to indistinct flow laminae, very fine grained, composed of quartz potassic feldspar, and plagioclase in about equal proportions, about 5 percent biotite (as minute flakes), and in places 1 to 5 percent minute cubes of pyrite. Contains few small quartz and plagioclase subhedral phenocrysts as long as $1 \mathrm{~mm}$. Probably intrusive into, but possibly a pendant in, biotite quartz monzonite.

Latite porphyry. - Mledium- to dark-gray, brownishweathering, hard, massive to rarely flow-laminated porphyry. Mastly latite in composition, but ranges to quartz latite and possibly to dacite and mafic andesite. Composed of scattered to numerous phenocrysts (as much as 30 percent of rock mass) as long as $3 \mathrm{~mm}$ in fine-grained groundmass. Phenocryst are either potassic feldspar (orthoclase) or plagioclase or both; in most places phenocrysts partly resorbed and altered to sericite, in some places replaced by quartz. Chlorite(?) and iron oxides commonly present as replacement of small phenocrysts of hornblende(?) or biotite(?). Groundmass composed of potassic and plagioclase feldspars in variable proportions, sericite, chlorite(?), and iron oxides. Epidote common as fillings of fractures and cavities. Fractures in rock commonly filled with iron orides and silica.

Latite porphyry breccia.-Same rock as latite porphyry, but fragmental; composed of scattered to numerous unsorted angular fragments of various sizes as large as $20 \mathrm{~cm}$ in matrix of latite porphyry. Rock devoid of planar structures. Probably a vent breccia.
Basalt porphyry.-Dark-gray mafic rocks of somewhat variable composition; massive, fine-grained. Composed of scattered to abundant (as much as 20 percent of rock mass) relict phenocrysts of plagioclase, pyroxene, and amphibole in fine-grained groundmass of mostly lathy plagioclase, with sericite, chlorite, and iron oxides. Phenocrysts partly resorbed and recrystallized to fine-grained texture; in some places replaced by epidote and calcite. In places rock contains scattered to abundant vesicles as large as $1 \mathrm{~cm}$ filled with epidote or epidote and calcite. In East Ord Mountain much of rock nearly devoid of phenocrysts.

Diorite porphyry.-Dark-gray, massive, hard, finegrained porphyritic diorite composed of plagioclase and dark grains; from 20 to 30 percent of rock mass composed of partly resorbed feldspar phenocrysts as long as $2 \mathrm{~mm}$; most phenocrysts are of plagioclase, a few are of potassic feldspar.

\section{Felsinte}

White, massive to rarely flow-laminated, hard but nonporcelaneous, very fine grained felsite composed mostly of potassic feldspar (orthoclase) and some quartz and magnetite; contains scattered phenocrysts as long as $1 \mathrm{~mm}$ of sodic plagioclase and flakes of biotite as wide as $1 \mathrm{~mm}$. Slightly iron stained on fractures but otherwise unaltered. Intrusive into metasedimentary and older granitic rocks. Age, presumably $\mathbb{M}$ esozoic (Cretaceous?).

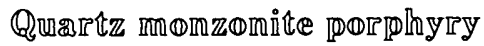

Light-gray, tan-weathering, massive to somewhat foliated granitic porphyry; composed of scattered phenocrysts as long as $1 \mathrm{~cm}$ of potassic feldspar in fine- to mediumgrained groundmass of quartz, potassic feldspar, and sodic plagioclase in about equal proportions, and scattered flakes of biotite. Forms dikes as wide as 70 feet in metasedimentary and older granitic rocks. Age, presumably Mlesozoic (Cretaceous?).

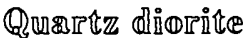

Gray, massive, equigranular medium-grained (average grain size $2 \mathrm{~mm}$ ) granitic rock composed of about 10 to 20 percent quartz, 10 to 20 percent potassic feldspar (orthoclase), 45 to 55 percent plagioclase (oligoclase-andesine), 10. to 20 percent biotite, 0 to 5 percent hornblende, and a total of less than 2 percent sphene, apatite, zircon, and magnetite. Rock unaltered. Age, Mlesozoic, possibly a mafic facies of quartz monzonite, but presumably older.

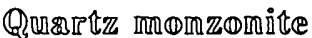

Gray-white, massive, equigranular, medium-grained (average grain size about $2 \mathrm{~mm}$ ) granitic rock composed of quartz, potassic feldspar, and plagioclase (oligoclase), generally in equal proportions, 2 to 5 percent biotite (as scattered euhedral tablets from 1 to $3 \mathrm{~mm}$ in diameter) and a total of less than 2 percent sphene, apatite, zircon, and magnetite. Rock unaltered. Intrusive into most other pre-Tertiary rocks. Age, presumably Cretaceous, passibly Late Jurassic.

\section{CLNOZOIC STDIMIENTARY AND VOLCANIC ROCKS

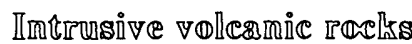

Small volcanic masses and dikes, intrusive into preTertiary racks, passibly in part extrusive. Age, presumably Tertiary. Composed of the following units: 
Felsitic rocks. - Light-colored felsites composed of quartz, potassic feldspar, and plagioclase, aphanitic to slightly porphyritic with scattered minute phenocrysts of plagioclase, and flakes of biotite; massive to somewhat flow-laminated, commonly with platy fracture parting, somewhat porous on weathered surface; pinkish- to creamy-white in Newberry Mountains and at north end of Iron Ridge; pinkishto purplish-brown farther southeast.

Andesite porphyry. - Light greenish- to brownish-gray andesite composed of numerous plagioclase phenocrysts as long as $4 \mathrm{~mm}$ and euhedral biotite flakes in aphanitic groundmass composed of plagioclase, potassic feldspar(?), and iron oxides. Forms dikes as wide as 20 feet and several possibly extrusive masses.

\section{Volcanic and sedimentary rocks}

Lava flows, pyroclastic, and fluviatile sedimentary rocks. Maximum exposed thickness of sequence about 10,000 feet. Base exposed only north of Kane Wash, unconformable on pre-Tertiary rocks. Age, presumably Tertiary, probably Miocene or older as indicated by stratigraphic position northwest of quadrangle. Composed of the following rock units:

Tuff-breccia.-Composed of angular fragments as large as 8 inches of pink to brown felsitic to andesitic rocks in massive to poorly bedded matrix of white and light-green to tan, lithic to sandy tuff. Forms lenses as thick as 150 feet in lower part of sequence.

Andesite and dacite. - Dark- to medium-brown, massive, hard, porphyritic, nonvesicular, except for scoriaceous flow east of Silver Bell mine. Mostly andesite composed of scattered to numerous phenocrysts (as much as 30 percent of rock mass) of plagioclase as long as $2 \mathrm{~mm}$, potassic feldspar (orthoclase), and few small dark phenocrysts of oxyhornblende(?), in aphanitic groundmass of plagioclase, hematite(?) dust, and black magnetite. Dacite similar but contains scattered irregular phenocrysts of quartz, some as large as $\mathbf{5 m m}$ and forming as much as $\mathbf{5}$ percent of rock mass. In Newberry Mountains forms brown extrusive mass possibly 600 feet thick; in Box Canyon area forms reddish-brown flows as thick as 150 feet.

Fanglomerate.-Unsorted subrounded cobbles and boulders as large as 3 feet in diameter in gray fragmental matrix; in Newberry Mountains fragments mostly of porphyry complex and granitic rocks (mostly biotite quartz monzonite); in Box Canyon area fragments mostly quartz monzonite in light-gray arkosic matrix.

Sandstone.-Light-gray, pink to red, bedded, mediumto coarse-grained, commonly pebbly, arkosic; forms units as thick as $\mathbf{1 5 0}$ feet in Box Canyon area.

Basalt. - Black, massive, commonly vesicular basalt composed of scattered to numerous subhedral phenocrysts of olivine (partly altered to iddingsite), a few phenocrysts of plagioclase, in fine-grained groundmass of lathy plagioclase (labradorite), green pyroxene (augite), and magnetite. On weathered surface altered olivine and plagioclase phenocrysts leached out. Vesicles sparse to abundant, commonly filled with calcite, quartz, and(or) chalcedony; veinlets of same minerals and of jasper common. Basalt weakly coherent on weathered surface. Forms numerous flows, mostly in upper part of sequence.

\section{Sedimentary rocks}

Sequence of moderately consolidated fluviatile sedimen- tary rocks and few lenses of volcanic rocks. Total exposed thickness about 3,000 feet. Probable unconformity at base in Kane Wash area. Age, presumably Tertiary, most probably Miocene. Composed of the following rock units:

Tuff.-Crea my-white, poorly bedded, fine- to mediumgrained friable tuff composed almost entirely of glass shards, contains scattered flakes of biotite, phenocrysts of feldspar, and small angular fragments of andesite or dacite; as thick as $\mathbf{5 0}$ feet, present only north of Kane Wash, at or near base of fanglomerate.

Granitic breccia.-Dark-gray to reddish-gray, massive breccia composed of unsorted angular fragments of biotite quartz monzonite; probably a landslide breccia at base of fanglomerate sequence east of Box Canyon where in contact with pre-Tertiary rocks.

Sandstone.-Light-gray to red, bedded, fine- to coarsegrained arkosic sandstone exposed in Box Canyon area, as thick as 700 feet, conformable on basalt of underlying volcanic and sedimentary rocks, grades upward and laterally eastward into conglomerate and sandstone.

Conglomerate and sandstone.-Gray to red conglomerate of poorly to moderately sorted cobbles and small boulders of same detritus as overlying fanglomerate, embedded in coarse sandstone matrix, and interbedded gray coarsegrained pebbly arkosic sandstone; as thick as $\mathbf{5 0 0}$ feet in Box Canyon area, grades upward and laterally eastward into fanglomerate.

Fanglomerate.-Gray, massive to crudely bedded fanglomerate composed of unsorted subrounded boulders, cobbles, and pebbles derived mostly from rocks of porphyry complex and biotite quartz monzonite, some from other plutonic rocks, including hornblende diorite gabbro, embedded in fragmental matrix; in Box Canyon area includes fragments of Tertiary andesite and in Newberry Mountains fragments of Tertiary basalt and andesite. Forms bulk of sequence; as thick as 1,800 feet in Box Canyon area, 500 feet in Newberry Mountains. Deposited by torrential downpours as alluvial fans, derived mostly from area to southwest.

Basalt.-Black vesicular basalt similar to that of underlying volcanic and sedimentary rock sequence described above. Forms a few small lenses as thick as 70 feet in fanglomerate.

\section{Volcanic and sedimentary rocks of southern areas}

Fluviatile sedimentary rocks and basalt; unconformity at base. Age, probably late Pliocene or early Pleistocene. Composed of the following units:

Sandstone. - Light-buff to gray-white, friable, bedded to massive, fine- to coarse-grained, arkosic; contains some interbedded light reddish- to greenish-gray micaceous gritty sandy siltstone; upper part contains light-gray conglomerate with subrounded pebbles and cobbles, mostly of biotite quartz monzonite, others of rocks of porphyry complex. Maximum exposed thickness about 1,000 feet, base unexposed.

Fanglomerate.-Light-gray, unbedded, composed of subrounded fragments as large as 2 feet of granitic rocks in arkosic sandy matrix. Maximum thickness about 100 feet.

Basalt.-Black, massive, hard, nonvesicular, composed of scattered small phenocrysts of plagioclase and olivine in dark microcrystalline groundmass of lathy plagioclase (labradorite), green pyroxene(?), and magnetite. Extruded 
from small volcano (hill 4,335 feet) $13 / 4$ miles east of southwest corner of quadrangle and possibly from several small fissures farther east. Raximum thickness of extruded basalt about 70 feet.

\section{OIder frnglømergte}

Gray, indistinctly bedded fanglomerate compased of unsorted boulders, cobbles, and pebbles derived mostly from biotite quartz monzonite and porphyry complex, in friable fragmental matrix. As thick as 500 feet in Box Canyon area; unconformity at base. Age, presumably Pleistocene, possibly late Pliocene.

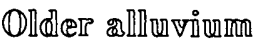

Gravel, sand, and silt of undeformed but dissected alluvial fans, derived from adjacent highlands; at least 10D feet thick; unconformity at base. Age, presumably Pleistocene.

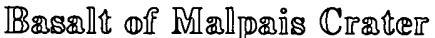

Black hard vesicular fine-grained basalt erupted from Rilalpais Crater (in N1/2 sec. $24, \mathbb{T}$. 7 N., R. $3 \mathbb{E}$.). Composed of scoriaceous basalt fragments at crater, lava flows elsewhere. Basalt composed of abundant small phenocrysts of olivine in fine-grained groundmass of lathy plagioclase (labradorite), pyroxene (augite?), and magnetite; vesicles most abundant at base and top of flows. Total thickness of erupted basalt as much as 100 feet. In Kane Wash overlies about 15 feet of older alluvium and is partly overlain by older alluvium. Basalt undeformed. Age, presumably Pleistocene.

\section{Sunrificiæl sedinments}

Unconsolidated sediments of undissected fill of valley areas. Maximum thickness about 100 feet. Composed of the following units:

Alluvium.-Coarse gravel of unsorted boulders and cobbles in sloping alluvial fans bordering mountains, grading downslope through cobble-pebble gravel into pebble gravel and sand in valley areas.

Clay.-Ricaceous clay and silt of mud flat or playa.

\section{MIINIS AND QUARIRIIS $\mathbb{C} \Phi$ Tproer}

A.-Copper prospect. NW1/4SE1//4 sec. $12, T$ T. 7 N., R. 2 E. Coatings and seams as thick as $1 / 4$ inch of chrysocolla, malachite, azurite, and hematite in fault zone 1 to 3 feet wide which dips $50^{\circ} \mathrm{N}$. in silicated, iron-stained latite porphyry. Explored, probably in late 1950's, by adit driven east about 50 feet opening into large 10 - by 20 -foot room at end.

B. $-\mathbb{L}$ and $L$ mine. $\mathbb{N}^{1} 1 / 2$ sec. $17, \mathbb{T} .7$ N., R. $3 \mathbb{E}$. Several shear zones 1 to 3 feet wide dipping steeply west in latite porphyry, contain thin seams of malachite and azurite and reportedly contain bornite, silver, and gold. Explored by two shafits, about 150 and 50 feet deep, and two adits, one driven north about 500 feet, the other driven east about 400 feet. Ore reportedly assayed as much as $\$ 15$ per ton in gold and 9 percent copper. Long idle. (W right and others, 1953, tab. list p. 14, no. 39.)

C.-Copper prospect. S1/2 sec. 25, T. 7 N., R. 2 E. A few malachite stains in iron-stained shear zone as wide as 3 feet that dips steeply northeast in granite and quartz monzonite. Explored by open pits.

D. - Copper_Strand mine. N1/2 sec. 9, T. 6 N., $\mathbb{R} .3 \mathbb{E}$.
Copper ore, mostly coatings of malachite, azurite, chrysocolla, and sparse chalcopyrite, bornite, and pyrite on fractures in shear zone striking northwest and dipping steeply southwest in garnet tactite. Explored by crosscut adit driven south west 600 feet and by 500 -foot shaft sunk on shear zone at portal of adit. Very little ore seen in adit. About 900 feet to northwest a similar (possibly the same) copper-stained shear zone explored by two open cuts. Ore treated at mill and leaching tanks, now dismantled. First operated in 1900; last production, 1940. (Wright and others, 1953, tab. list p. 7, no. 19.)

E.-Copper prospect. N N W 1/4SE1/4 sec. 6, T. 6 N., R. $4 \mathbb{E}$. Coatings of malachite and chrysocolla on fracture and shear surfaces in small masses of garnet tactite which are engulfed in biotite quartz monzonite. Explored by shallow pits in 1962.

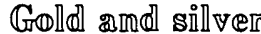

F.-Red Hills prospect. SW $1 / 4$ sec. 7, T. 6 N., R. 3 E. Gold erratically distributed in vuggy iron-stained quartz vein along contact of quartz latite with biotite quartz monzonite. Explored by two shallow shafts 200 feet apart and by 200 -foot adit. Idle since 1945 . (Wright and others, 1953, tab. list p. 54, no. 171, in part.)

G.-Cumberland (High Hope) mine. SW $1 / 4 \mathrm{SE}^{1 / 4} \mathrm{sec}$. 25, T. 6 N., R. 2 E. Free gold associated with pyrite, mareasite, and hematite in quartz vein which lies in shear zone 1 to 3 feet wide in biotite quartz monzonite. Zone strikes N. $20^{\circ}$ E., dips $80^{\circ} \mathrm{NW}$. parallel to dike of quartz monzonite porphyry to east. Zone explored by six shaf ts from 50 to 135 feet deep within 2,000 feet of strike length and by several drifts. Ore produced in 1939. (Wright and others, 1953, tab. list p. 31 no. 86.$)$

H. - Elsie mine. N1/2 sec. 36, T. 6 N., R. $2 \mathbb{E}$. Gold associated with arsenopyrite, pyrite, and copper carbonates in zone of quartz and iron oxides. Zone nearly vertical, strikes N. $20^{\circ} \mathrm{E}$., parallel to associated dike of quartz monzonite porphyry in biotite quartz monzonite. Explored by two shafts 250 and 150 feet deep about 500 feet apart. Active in early 1920's, output probably appreciable. Small production in 1935 and 1940, idle since. (W right and others, 1953; tab. list p. 33, no. 95.)

J.-Johnson mine. $\mathrm{SE} E^{1 / 4}$ ? sec. $36, \mathrm{~T} .6$ N., R. $2 \mathbb{E}$. Gold associated with pyrite and arsenopyrite in iron-stained quartz which lies in vertical shear zone 1 to 4 feet wide in biotite quartz diorite. Explored by 400 - foot crosscut adit and 250 feet of drifting each way along zone. Long idle. (Wright and others, 1953, tab. list p. 4A, no. 135.)

K.-Gold Peak mine. W1/2 sec. 31, T. 6 N., R. 3 I. Thee gold associated with pyrite in four parallel vertical northstriking veins mostly in biotite quartz monzonite. RMined from 120 -foot vertical shaft with level workings at 50 and 100 feet, and from open cuts. Active in early 1950's, reported output of more than $\$ 40,000$ prior to 1914 . Long idle. (W right and others, 1953 , tab. list p. 38 , no. 110.)

L._Silver Bell mine. S1/2 sec. $12, T$ T. 7 N., R. $4 \mathbb{E}$. Sparse green stains of malachite in shear zones in amygdaloidal basalt and underlying sandstone. Explored by adit driven southwest 1,050 feet; silver, lead, and gold reported (Wright and others, 1953, tab. list p. 83, no. 272) but none seen. No production reported. Long idle.

M.-Camp Rock placers (Clark Diggings). N $\mathbb{N}^{1 / 4 S W 1 / 4}$ sec. 28, T. 7 N., R. 3 E. Detrital gold in granitic gravel of 
alluviüm 2 to 25 feet thick on granite and quartz monzonite. Gold content of gravel reportedly ranges from $\$ 0.25$ to $\$ 1.25$ per yard. Prospected by numerous shallow pits and trenches, some to base of gravel, over area about 1,000 by 500 feet. Worked by dry washers prior to 1932 ; by washing and screening with water from well a quarter of a mile west from 1932 to 1939 . (Wright and others, 1953, tab. list p. 29 , no. 79 .)

\section{Iron}

N.-Camp Rock prospects. NE $1 / 4$ sec. 4 , T. 6 N., R. 3 E. Small body of magnetite-hematite iron ore in gangue of garnet-epidote tactite at contact of marble with intrusive biotite quartz monzonite exposed in small hill. Explored in 1955-1957 by shallow cuts; high magnetic anomaly under alluviated area to west and northwest tested by three holes at depths ranging from about 1,000 to 3,100 feet. Owned and operated since 1954 by Columbia Steel Corp.; idle since. (James Powers, Columbia Steel Corp., oral communication, 1958.)

P.-Ebony prospect. SW1/4SW1/4 sec. 15, T. 6 N., R. 4 E. Small body of magnetite-hematite iron ore as wide as 30 feet with some garnet and epidote; ore body nearly surrounds small ovate dolomitic marble pendant about 500 feet long engulfed in biotite quartz monzonite. Estimated reserve 100,000 tons ore, 40 to 50 percent iron. Prospected in 1950's by five open cuts. (Wright and others, 1953, tab. list p. 66 , no. 216 , in part.)

Q.-Bessemer quarries (Kaiser Steel Corp.). Secs. 27 and 28 , T. 6 N., R. $4 \mathrm{E}$. Iron ore, mostly of magnetite, some hematite and limonite, in nearly pure masses or disseminated in gangue of calcite-dolomite-diopside-epidotegarnet tactite zones along margins of small pendants of generally south-dipping dolomitic marble engulfed in biotite quartz monzonite and associated granitic rocks. Iron ore in fourteen bodies ranging in surface area from 2,800 to 50,000 square feet, estimated to contain total of $1,800,000$ tons of ore of all grades, 30 to 65 percent iron, about 25 percent workable. Four largest bodies contain 72 percent of total estimated tonnage ranging from 60 to 65 percent iron. Ore of each of four largest masses mined from shallow quarry; worked occasionally from 1945 to 1957 ; about 2,000 . tons of ore quarried in 1945; about 26,000 tons in 1951; several shallow test holes drilled in 1955-1957 on alluviated flat immediately south to test possible buried ore deposits owned and operated by Kaiser Steel Corp. since 1954; idle since 1957. (Wright and others, 1953, p. 91, in part.)

$R .-$ New Bessemer quarry. SE $1 / 4$ sec. $36, T .6$ N., R. 4 E., NE $1 / 4$ sec. 1 , T. 5 N., R. 4 E. Small body of magnetitehematite iron ore as wide as 100 feet, about 300 feet long, with garnet-epidote rock on north side of small pendant of dolomitic marble, engulfed in biotite quartz monzonite. Explored by large shallow quarry. About 4,000 tons of ore quarried in 1949. Also several very small masses of similar ore two-thirds of a mile N. $70^{\circ} \mathrm{W}$., explored by trenches. (Wright and others, 1953, tab. list p. 68, no. 223, in part.)

S.-Morris Lode (Van Buren group) prospect. $\mathbf{E}^{1 / 2} \mathrm{sec}$. 12, T. 5 N., R. 4 E., W1/2 sec. 7, T. 5 N., R. 5 E. Three bodies of magnetite-hematite iron ore in gangue of diopside, garnet, epidote, and calcite (average grade of ore about 37 percent iron) at contact of pendants of west-dipping dolomitic marble to west and intrusive biotite quartz monzonite to east; ore bodies about a quarter of a mile apart in northsouth alinement, range in width from 50 to 150 feet, in length from 100 to $\mathbf{4 0 0}$ feet; south mass largest. Ore bodies explored in 1955-1958 by shallow pits and by scraping away of overburden; high magnetic anomaly under alluviated gap area between ore bodies tested by nine holes to depths from 150 to 955 feet; eight penetrated ore zones ranging in thickness from 87 to 921 feet, with average grade of 37.3 percent iron. Owned and operated since 1954 by Kaiser Steel Corp.; idle since 1957. (Wright and others, 1953, p. 97-98.)

\section{Barite}

T.-Barite prospect. NE1/4SE1/4 sec. 20, T. 7 N., R. 3 E. Barite vein 1 foot wide, 10 feet long at surface, dips steeply west in latite porphyry. Prospected by shallow pit.

\section{Volcanic cinders}

U.-Malpais Crater cinder deposit. N1/2 sec. $24, \mathrm{~T} .7 \mathrm{~N}$., R. 3 E. Crater of Malpais volcanic cone composed of black scoriaceous basalt fragments, mostly of pebble and cobble size, and some volcanic bombs; fragmental rock capped by basalt of Malpais flow that forms rim of crater. Small tonnage of scoriaceous fragments quarried from crater in late 1950's.

\section{REFERENCES}

Gardner, D. L., 1940, Geology of the Newberry and Ord Mountains, San Bernardino County, California: California Jour. Mines and Geology, v. 36, no. 3, p. 257-292.

Vaughan,F.E.1922,Geology of the San Bernardino Mountains north of San Gorgonio Pass [California]: California Univ., Dept. Geol. Sci. Bull., v. 13, no. 9, p. 319-411.

Wright, L. A., Stewart, R. M., Gay, T. E., Jr., and Hazenbush, G. C., 1953, Mines and mineral deposits of San Bernardino County, California: California Jour. Mines and Geology, v. 49, nos. 1 and 2, p. 49-259, with tabulated list, 192 p. 